\title{
Immunohistochemical characterisation of immune cells in fixed equine endometrial tissue: a diagnostic relevant method
}

\author{
Nicole Rudolph, Heinz-Adolf Schoon and Sandra Schöniger \\ Institute of Pathology, Faculty of Veterinary Medicine, University of Leipzig, Germany
}

\begin{abstract}
Summary: Endometrial diseases are the major cause of subfertility in mares. The detection of subclinical diseases requires the histopathological examination of an endometrial biopsy. To prevent autolysis endometrial biopsies have to be fixed prior to their submission to the diagnostic laboratory. The most frequent type of chronic subclinical inflammation is non-suppurative endometritis. An immune mediated pathogenesis is suspected. Type 1 and type 2 adaptive immune responses exist; these are mediated by CD4+ helper T cells, CD8+ cytotoxic T cells, CD20+ B cells, plasma cells as well as polarized macrophages. In equine research, CD172a has been proposed as panmacrophage marker, CD14 and CD206 as markers of M1 and M2 polarisation, respectively; immunostaining for these antigens was only performed on cryostat sections of unfixed equine tissue. The aim of the present study was a) to establish an immunohistochemical method for the detection of macrophages in fixed equine tissue samples and b) to characterize the immune cell populations in fixed endometria with and without chronic endometritis. In regard to the former objective, immunostaining for CD172a, CD14 and CD206 was performed on paraffin embedded equine tissue with resident macrophages (lymph node, liver, small intestines) fixed either with IHC Zinc Fixative or $10 \%$ neutral buffered formalin. In regard to the latter, immune cell populations in zinc fixed paraffin embedded (ZnFPE) endometrial biopsies of mares without endometritis $(n=4)$ and those with a superficial non-suppurative endometritis $(n=28)$ were compared. This study established an immunohistochemical method for the detection of the examined macrophage markers within fixed tissue samples, i.e. ZnFPE (CD172a, CD14, CD206) and formalin fixed paraffin embedded (FFPE) tissue after antigen retrieval (CD172a, CD206). It indicated that CD172a likely represents a pan-macrophage marker also in the equine endometrium. Immunohistochemical phenotyping showed that non-suppurative endometritis is mainly a $T$ cell mediated disease with participation of plasma cells. In addition to CD4 + and CD8 $+T$ cells, results indicate the presence of CD4-/CD8- double negative T cells. B cells and/or macrophages were observed in 15 cases. Endometrial macrophages expressed mainly CD172a and only rarely CD206, whereas CD1 4 was not detected. Notably, examined endometria showed a high variability in the numbers of T cell populations as well as plasma cells. This suggests the existence of subforms of this disease that may even differ in pathogenesis and etiology. The established method of immunophenotyping can be included in the routine diagnostic work-up of equine endometrial biopsies and can be beneficial for the identification of new therapeutic approaches. Its standardized application will likely assist to uncover immunological features that may predispose mares to develop persistent endometritis. The successful future application of this method will likely be beneficial for the genital health of individual mares, it also may help to prevent financial losses of the horse breeding industry.
\end{abstract}

Keywords: endometrium, fixed tissue, immunohistochemistry, immune cells, macrophage and lymphocyte subpopulations, mare

Citation: Rudolph N., Schoon H.-A., Schöniger S. (2017) Immunohistochemical characterisation of immune cells in fixed equine endometrial tissue: a diagnostic relevant method. Pferdeheilkunde 33, 524-537; DOI 10.21836/PEM20170601

Correspondence: PD Dr. Sandra Schöniger, University of Leipzig, Faculty of Veterinary Medicine, Institute of Pathology, An den Tierkliniken 33, 04103 Leipzig, Germany.sandra.schoeniger@vetmed.uni-leipzig.de

\section{Introduction}

Endometrial diseases are an important cause of reduced fertility in mares (Schoon et al. 1997, Kenney and Doig 1986) and thus have a significant economic impact on the horse breeding industry (de Mestre 2013, LeBlanc and Causey 2009). These include endometritis, degenerative diseases (endometrosis and angiosclerosis) and glandular differentiation disorders (Schoon et al. 2000 and 1997, Kenney and Doig 1986).

In regard to the involved cell population(s), endometritis can be classified into different forms, i.e. suppurative, non-suppurative, granulomatous and endometritis eosinophilica (Ellenberger et al. 2006, Schoon et al. 1997, Kenney and Doig 1986). With the exception of bacterial induced suppurative endometritis, the other forms of endometritis are usually clinical unapparent (LeBlanc and Causey 2009, Schoon et al. 1997) and can only be diagnosed by the histopathological examination of an endometrial biopsy (Schoon et al.
1997). Retrospective studies on endometrial biopsies revealed a $20-38 \%$ incidence of endometritis; the non-suppurative type was most frequently diagnosed (Ebert et al. 2014, Schoon et al. 1997). Bacterial culture is usually negative for the detection of uterine pathogens (LeBlanc and Causey 2009, Schoon et al. 1997) and so far a specific therapy is missing (LeBlanc and Causey 2009). An immune-mediated pathogenesis has been suggested. In contrast, histiocytic or granulomatous inflammation of the equine endometrium is rarely reported (Ellenberger et al. 2006). Possible causes are bacterial infections, aberrant parasite migration and the presence of intralesional foreign material, e.g. lipids (Ellenberger et al. 2006).

Macrophages act as immediate defence against pathogens and stimulate the adaptive immunity by interacting as antigen presenting cells with helper T cells (Kidd 2003). Antigens of intracellular pathogens mainly activate Th1 cells, whereas Th2 cells respond to extracellular pathogens and are involved in allergic reactions (Kidd 2003). Both types of immune reac- 
tions also involve cytotoxic $T\left(T_{c}\right)$ cells and polarized macrophages (M), named as Tc1/Tc2 cells and M1/M2 macrophages, respectively (Kidd 2003, Woodland and Dutton 2002, Mills et al. 2000). These immune responses serve to maintain or restore tissue homeostasis (Bain and Mowat 2014, Kidd 2003). Their dysregulated activation, however, can lead to inflammatory diseases (Bain and Mowat 2014, Kidd 2003).

In equine research, CD172a has been proposed as a panmacrophage marker (Dakin et al. 2012, Tumas et al. 1994), CD1 4 and CD206 as marker for M1 and M2 macrophages, respectively (Dakin et al. 2012). All previous immunohistochemical studies on these molecules in equine organs were performed on cryostat sections prepared from unfixed frozen tissue (Dakin et al. 2012, Flaminio et al. 2007, Kumar and Timoney et al. 2005). Endometrial biopsies collected for a routine diagnostic work-up, however, need to be immediately fixed to prevent autolysis. Thus, the material available for studies on disease associated immune cell populations of the equine endometrium mainly represents fixed tissue samples. Therefore, the aim of the present study was a) to establish an immunohistochemical method for the detection of macrophages in fixed equine tissue samples and b) to characterize the immune cell populations in fixed endometria without and with chronic endometritis.

\section{Material and Methods}

Immunohistochemistry for the detection of macrophages in fixed equine tissues - establishment of this method

\section{Animals and tissue samples}

Three Thoroughbred mares of unknown age and a 2-year-old Warmblood mare were euthanized and submitted for a post mortem examination. Within $30 \mathrm{~min}$ after euthanasia, from each mare several tissue samples (up to $0.8 \times 0.8 \times 0.8 \mathrm{~cm}$ ) of organs with macrophage populations (liver, small intestine, intestinal lymph node) and endometrium were obtained; these showed no gross lesions. Anamnestic and clinical data were not available. Immediately after collection, samples of each organ were fixed for 48 hours (hrs) in 10\% neutral buffered formalin or the IHC Zinc Fixative (BD Biosciences Pharmingen, Heidelberg, Germany). Fixed tissues were embedded in paraffin wax. Frozen and fixed paraffin embedded tissue samples were processed routinely for histopathology and immunohistochemisty as described by Huth et al. (2014).

\section{Histology}

Formalin fixed paraffin embedded (FFPE) as well as zinc-salt fixed paraffin embedded (ZnFPE) tissue sections were stained with haemalaun and eosin (HE). Serial sections of ZnFPE samples were also investigated with a picrosirius red stain for the detection of mast cells (turquoise cytoplasm) and methyl green-pyronin for the identification of plasma cells (pink cytoplasm).

\section{Immunohistochemistry}

The following monoclonal antibodies were investigated on fixed tissue samples: CD172a (clone DH59B, Washington State University, Pullman, USA), CD1 4 (clone biG 14, biome- tec, Greifswald, Germany) and CD206 (clone 15-2, abcam, England, UK). The peroxidase anti-peroxidase complex method (PAP method, rat anti-mouse immunoglobulin $G$ and mouse-PAP, Dianova, Hamburg, Germany) as well as two immune-peroxidase polymer methods, i.e. N-Histofine ${ }^{\circledR} \mathrm{Sim}$ ple Stain Max PO (Nichirei Biosciences Inc., Tokyo, Japan) and EnVision ${ }^{\circledR}+$ Dual Link System-HPR (Dako North America Inc., California, USA) were used with and without antigen retrieval. Details on the PAP-method are described by Huth et al. (2014). The polymer methods were used according to the manufacturer's instructions. Prior to the immunostaining, fixed tissue samples were dewaxed and rehydrated. All sections were treated with a $0.5 \%$ hydrogen peroxide solution in methanol for blocking the endogenous peroxidase. To prevent non-specific binding, sections were preincubated in $5 \%$ normal goat serum diluted in Tris-buffered saline (TBS) for $30 \mathrm{~min}$ at room temperature (RT). Antibodies and the PAPcomplex were diluted in TBS containing $5 \%$ goat serum. Washing steps were performed with TBS.

Antigen retrieval was applied solely to sections of FFPE tissue samples. Two different methods were used, i.e. heating in citrate buffer and protease treatment. After their incubation in citrate buffer $(10 \mathrm{mM}, \mathrm{pH} 6)$, sections were heated for $25 \mathrm{~min}$ at $95^{\circ} \mathrm{C}$ and then kept at RT for $17.5 \mathrm{~min}$. For the protease antigen retrieval, sections were incubated at $37^{\circ} \mathrm{C}$ in sodium phosphate buffer ( $\mathrm{pH} 7.2)$ for 5 min and subsequently treated with $0.05 \%$ protease (Bacillus licheniformis protease, P5380, Sigma-Aldrich Chemie GmbH, Taufkirchen, Germany) diluted within sodium phosphate buffer. A negative control was performed for each immunostained section; for this the primary antibodies were substituted by a non-related monoclonal mouse immunoglobulin $G$ antibody. Sections were counterstained with Papanicolaou solution (Merck KGaA, Darmstadt, Germany).

\section{Evaluation of the immunoreaction}

The immunoreactivity of the primary antibodies in the tissue sections treated with different fixation and antigen retrieval methods was compared. The aim of this analysis was to identify the immunohistochemical method that is most suitable for the identification of macrophage populations in equine tissue.

\section{Immunohistochemical phenotyping of immune cell popula- tions}

Endometrial tissue samples of mares without endometritis and with superficial non-suppurative endometritis

Animals and tissue samples

Immune cell populations of the non-inflamed endometrium were compared with those present in endometrial tissue samples with mild superficial non-suppurative endometritis. Endometrial tissue samples of 28 mares were examined. Zinc fixed tissue samples from 27 mares were obtained as biopsy submissions; the remaining tissue sample was collected from a pony during a post mortem examination and fixed in $\mathrm{IHC}$ Zinc Fixative as well. Four mares had no evidence of endometritis and the remaining mares had a mild superficial non-suppurative endometritis. Available anamnestic data are provided in Table 1. 
Histology

The histological examination was performed on HE stained ZnFPE tissue sections. Evaluated was the functional morphology of endometrial glands as well as the presence of endometritis, endometrosis, angiosclerosis as well as glandular maldifferentiation. The results are depicted in the Table 1. In addition, a methyl green-pyronin stain for the better visualization of plasma cells was performed. Endometritis is defined as the presence of inflammatory cells/immune cells that exceed the physiological range; this evaluation has to be performed under consideration of the respective stage of the endometrial cycle (Schoon et al. 1992, Brunckhorst et al. 1991).

Immunohistochemistry

Primary antibodies for the detection of macrophages (CD172a, CD14 and CD206) and those for the identification of T lymphocytes (CD3+, CD4+, CD8+) as well as B cells (CD20) were used. The applied lymphocyte markers were cross-reactive rabbit anti-human CD3 (clone F7.2.38, Dako
North America Inc., California, USA), mouse anti-equine CD4 (clone HB61A, Washington State University, Pullman, USA, Kydd et al. 1994), mouse anti-equine CD8 (clone HT14A, Washington State University, Pullman, USA, Kydd et al. 1994) and mouse anti-human CD20 (clone L26, Dako North America Inc., California, USA). CD172a, CD14 and CD3 immunostaining was performed by the use of the PAPmethod, whereas N-Histofine ${ }^{\circledR}$ Simple Stain Max PO was applied to detect CD206, CD4, CD8 and CD20. Tissue samples of equine liver, small intestine and intestinal lymph node were used as positive controls. In the negative controls, the primary antibodies were substituted by a non-related monoclonal mouse immunoglobulin $\mathrm{G}$ antibody.

Evaluation of the cellular phenotypes

A semiquantitative evaluation of the numbers of CD172a+, CD14+ and CD206+ macrophages, CD3+, CD4+, CD8 + and CD20+ lymphocytes as well as plasma cells was performed in serial sections within 5 randomly selected high

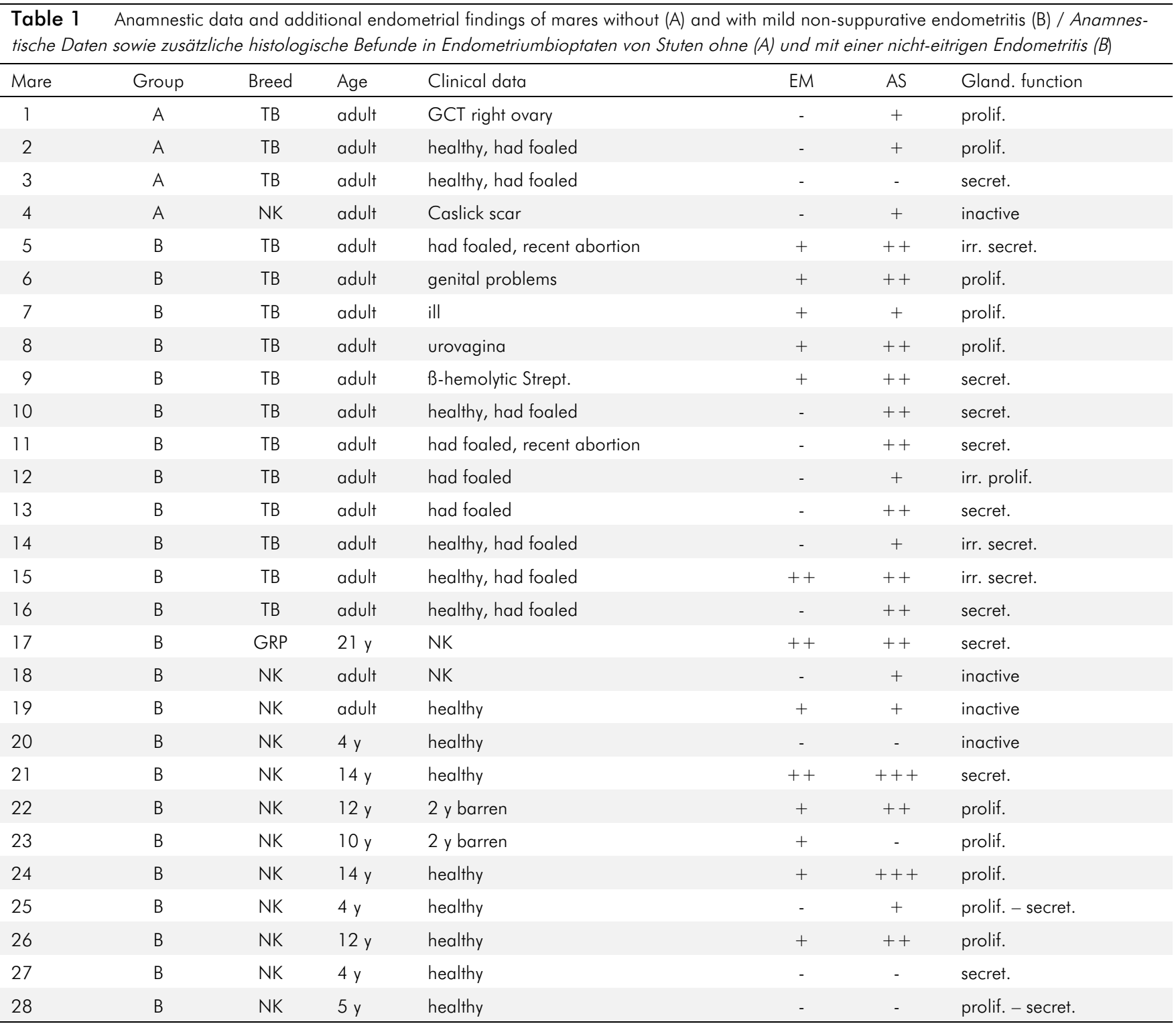

$\mathrm{AS}=$ angiosclerosis; GCT = Granulosa cell tumor; Gland. = glandular; GRP = German riding pony; EM = endometrosis; irr. = irregular; NK = not known; prolif. $=$ proliferative; secret. $=$ secretory; Strept. $=$ Streptococcus spp. isolated from an uterine swab; TB $=$ Thoroughbred; $y=y e a r s ;-$ absent; + mild;

++ moderate; +++ marked 
power fields (HPFs). Positive cells were counted separately within the luminal and glandular epithelium, the stratum compactum and the stratum spongiosum.

Tissue samples of a mare with marked non-suppurative and histiocytic endometritis

A 2.5-year-old German sportsmare with emaciation, chronic enteritis, pneumonia and uveitis was euthanized due to a poor prognosis and submitted for a post mortem examination. Gross examination showed a marked granulomatous to necrotizing pneumonia and a multifocal necrotizing colitis as well as enlarged pulmonary and intestinal lymph nodes.

From this mare, tissue samples of organs with macroscopic lesions as well as multiple other organs (see below) including uterus were collected. These included native frozen tissue samples as well as FFPE and ZnFPE samples.

\section{Histology}

Histological examination was performed on HE stained sections of endometrium, organs with macroscopic lesions (lungs, colon, lymph nodes) and additional tissues (uvea of both eyes, brain, liver, kidneys, heart, skeletal muscle, adrenal gland). A methyl green-pyronin stain was applied to tissue sections of the endometrium to better visualize plasma cells.

\section{Immunohistochemistry}

Fixed endometrial tissue was used to detect $\mathrm{T}$ lymphocytes (CD3), B lymphocytes (CD20), CD4 + and CD8 + T cells and CD172+,CD14+ and CD206+ macrophages. In addition, the macrophage markers lysozyme (rabbit anti-human, clone EC 3.2.1.17, Dako North America Inc., California, USA) and myeloid/histiocyte antigen (mouse anti-human, clone MAC 387, Dako North America Inc., California, USA) were applied. An immunohistochemical analysis with antibodies detecting Equine Herpesvirus-1-, pseudorabies-, rabies- and Bornavirus-antigens was performed on fixed tissue samples of brain, lungs, liver and endometrium (Institute of Pathology, Faculty of Veterinary Medicine, University of Leipzig, Germany).

\section{Microbiology}

Unfixed tissue samples of lungs, intestines, mesenteric lymph node, liver and kidney were submitted for bacterial culture
(Landesuntersuchungsanstalt für das Gesundheits- und Veterinärwesen Sachsen, Leipzig, Germany). A polymerase chain reaction (PCR) was performed on native tissue samples of liver, spleen, brain, kidney and lymph nodes to rule out an infection with Borrelia spp. (Institute for Infectious Diseases and Zoonoses, Department of Veterinary Sciences, Faculty of Veterinary Medicine Ludwig-Maximilians-University, Munich, Germany).

Endometrial tissue samples of two mares with granulomatous endometritis

The two cases of granulomatous endometritis were received as formalin fixed biopsies; mares were 20 and 21 years old. Fixed tissue samples were processed routinely for histology (HE staining) and immunohistochemistry for the detection of CD172a and CD206.

\section{Results}

Immunohistochemistry for the detection of macrophages in fixed equine tissues - establishment of this method

The results of the immunoreactivity of the applied macrophage marker, i.e. CD172a, CD14 and CD206 in fixed tissue sections are summarized in Table 2 and illustrated in Figure 1 and 2. In all examined cases, picrosirius red and methyl green-pyronin stained serial sections were used to rule out that the immunopositive cells may represent mast cells or plasma cells, respectively.

\section{Anti-CD172a antibody}

The zinc-salt fixation together with the PAP-method was revealed as the most appropriate method. The markedly reduced immunoreactivity after formalin fixation without antigen retrieval was likely attributed to antigen-masking. After antigen retrieval with citrate buffer pretreatment mainly restored immunoreactivity in formalin fixed tissues. Small numbers of positive mononuclear cells consistent with macrophages were detected in liver, small intestine, lymph node and uterus (endometrium). In addition, neutrophils, eosinophils and intravascular monocytes were also immunopositive. The immunostaining was located within the outer plasma membrane and the cytoplasm.

Table 2 Detection of CD172a, CD14 and CD206 immunopositive macrophages in fixed equine tissues / Nachweis CD172a, CD14 und CD206 immunpositiver Makrophagen in fixiertem Gewebe des Pferdes

\begin{tabular}{lcccc}
\hline Fixation & & Formalin & \multicolumn{2}{c}{ Zinc Fixative } \\
\hline Marker/Antigen Retrieval & None & Citrate buffer & Protease & None \\
\hline CD172a & $-/+$ & $+(+)$ & $-/+$ & +++ \\
CD14 & - & - & - & $+(+)$ \\
CD206 & - & - & +++ & $+(+)$ \\
\hline
\end{tabular}

- lack of immunostaining; -/+ low sensitivity; $+(+)$ mild to moderate sensitivity; +++ high sensitivity

CD172a = mouse monoclonal antibody, clone DH59B, Monoclonal antibody center, Washington State University, USA

$\mathrm{CD} 14$ = mouse monoclonal antibody, clone biG14, biometec, Greifswald, Germany

CD206 = mouse monoclonal antibody, clone 15-2, abcam, England, UK

Formalin $=10 \%$ neutral buffered formalin; Zinc Fixative $=$ IHC Zinc Fixative, BD Biosciences Pharmingen, Heidelberg, Germany 
Anti-CD14 antibody

The applied anti-CD14 antibody revealed a mild to moderate positive reaction only in ZnFPE tissues with the PAP-method and the immune-peroxidase polymer method (EnVision ${ }^{\circledR}+$ Dual Link System-HPR). FFPE-material with and without anti-

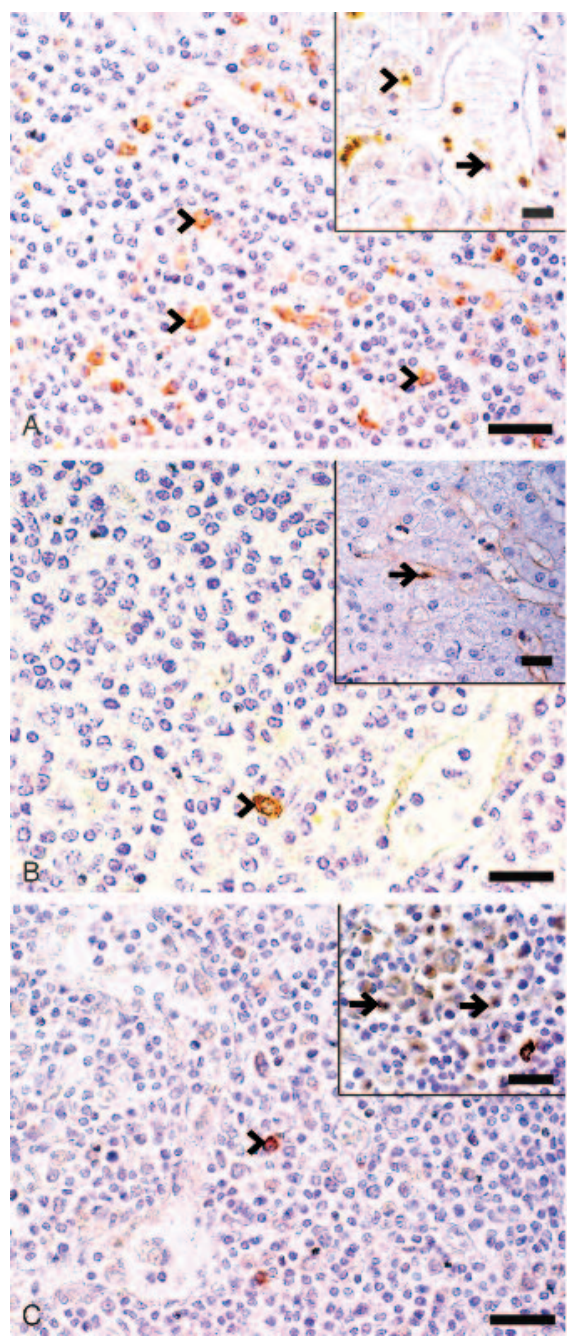

Fig. 1 Zinc fixed tissue samples: immunohistochemical detection of CD172a (A), CD206 (B) and CD14 antigen (C). (A) Moderate numbers of CD172a immunopositive macrophages are detected within the lymph node (arrowheads). Bar $=20 \mu \mathrm{m}$. Inset: Immunopositive macrophages (arrowhead) and monocytes (arrow) are observed within the liver. Bar $=20 \mu \mathrm{m}$. (B) Occasional CD206+ macrophages (arrowhead) are present within the lymph node. Bar $=20 \mu \mathrm{m}$. Inset: Within the liver, sinusoidal endothelial cells express CD206 antigen (arrow). Bar $=20 \mu \mathrm{m}$. (C) Lymph node tissue contains a few CD14 immunopositive macrophages (arrowhead). Bar $=20 \mu \mathrm{m}$. Inset: Neutrophils within the lymph node sinus showed a positive immunostaining for CD14 (arrows). Bar $=20 \mu \mathrm{m}$.

Zink fixiertes Gewebe: immunhistochemischer Nachweis von CD172a- (A), CD206- (B) und CD14- Antigen (C). (A) Nachweis einer mäßigen Anzahl an CD172a-immunpositiven Makrophagen im Lymphknotengewebe (Pfeilspitzen). Messbalken $=20 \mu \mathrm{m}$. Inset: Detektion immunpositiver Makrophagen (Pfeilspitze) und Monozyten (Pfeil) in der Leber. Messbalken =20 $\mu \mathrm{m}$. (B) Lymphknotengewebe mit vereinzelten CD206 + Makrophagen (Pfeilspitze). Messbalken $=20 \mu \mathrm{m}$. Inset: Sinusoidale Endothelzellen der Leber exprimieren ebenfalls CD206 (Pfeil). Messbalken $=20 \mu \mathrm{m}$. (C) Lymphknotengewebe mit wenigen CD14-immunpositiven Makrophagen (Pfeilspitze). Messbalken $=20 \mu \mathrm{m}$. Inset. Detektion CD14+ neutrophiler Granulozyten (Pfeile) im Lymphknotengewebe. Messbalken=20 $\mathrm{mm}$. gen retrieval was immunonegative. Scattered positive mononuclear cells consistent with macrophages were observed within the lymph node and small intestines. The antibody also stained neutrophils and eosinophils. The immunosignal was located within the outer cell membrane and the cytoplasm.

\section{Anti-CD206 antibody}

The most sensitive method to detect CD206+ cells was the protease pretreatment of FFPE tissue samples with $\mathrm{N}$-Histofine ${ }^{\circledR}$ Simple Stain Max PO. Although the zinc-salt fixation was less sensitive, it still allowed the detection of CD206+ cells. Scattered immunopositive mononuclear cells consistent with macrophages were located within the liver, small intestine, lymph node and uterus (endometrium). The antibody also labelled endothelial cells of hepatic sinusoids. The immunopositive cell populations showed staining of their outer cell membrane and cytoplasm.

\section{Conclusion}

The zinc-salt fixation allowed the detection of all three macrophage markers, whereas the identification of CD172a+ and

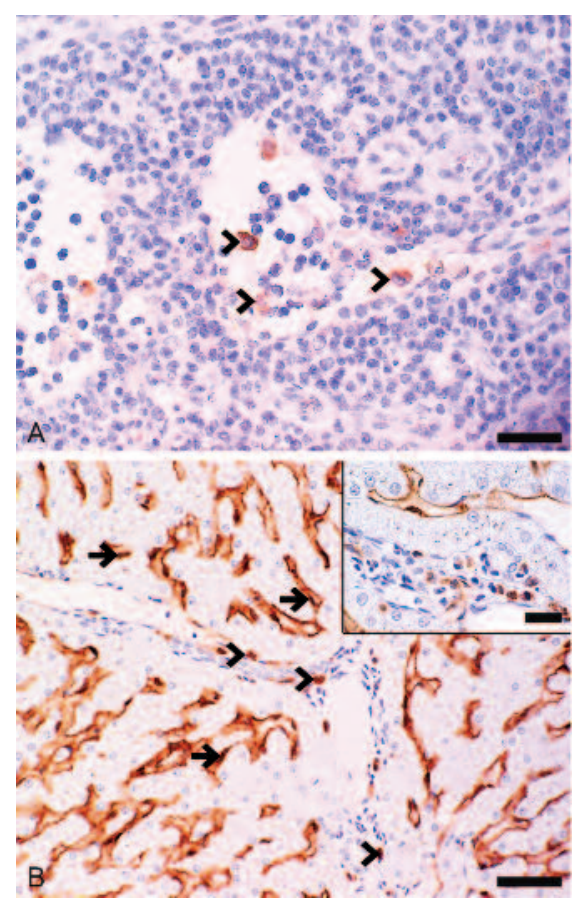

Fig. 2 Formalin fixed tissue samples: immunohistochemical detection of CD172a (A) and CD206 (B). (A) Within the lymph node, moderate numbers of $\mathrm{CD} 172 \mathrm{a}$ immunopositive macrophages are detected (arrowheads). Bar $=20 \mu \mathrm{m}$. (B) Liver tissue with a positive CD206 immunoreaction within macrophages (arrowheads) and endothelial cells (arrows) of the hepatic sinusoids. Bar $=50 \mu \mathrm{m}$. Inset: The immunolabelled cells are depicted in a higher magnification. Bar $=20 \mu \mathrm{m}$.

Formalin fixiertes Gewebe: immunhistochemischer Nachweis von CD172a (A) und CD206 (B). (A) Nachweis einer mäßigen Anzahl an CD172a immunpositiven Makrophagen im Lymphknoten (Pfeilspitzen). Messbalken $=20 \mu \mathrm{m}$. (B) Detektion einer CD206-Expression in Makrophagen (Pfeilspitzen) und sinusoidalen Endothelzellen der Leber (Pfeile). Messbalken $=50 \mu \mathrm{m}$. Inset: Die immunmarkierten Zellen sind in einer höheren Vergrößerung dargestellt. Messbalken $=20 \mu m$. 
CD206 + macrophages was also possible in formalin fixed tissue.

Immunohistochemical phenotyping of immune cell populations

Endometrial tissue samples of mares without endometritis and with superficial non-suppurative endometritis

Clinical data of the mares and histological findings of the examined endometrial biopsies are listed in Table 1. The results of the semiquantitative evaluation of CD172a+, CD14+ and CD206+ macrophages, CD3+, CD4+, CD8 + and CD20+ lymphocytes as well as plasma cells are summarized in Table 3 and depicted in Figures 3 and 4, respectively. Overall, in the vast majority of healthy and diseased endometria, higher numbers of lymphocytes and macrophages were detected within the stratum compactum than within the stratum spongiosum. Tissue samples with endometritis contained higher average numbers of lymphocytes, macrophages and plasma cells than healthy endometria. CD14+ macrophages were absent within all analyzed endometrial tissue samples.

Endometria without endometritis

Luminal and glandular epithelium: All cases contained rare intraepithelial mononuclear cells. These represented solely $T$ lymphocytes; no B cells, plasma cells or macrophages were detected. CD8 + T cells were observed in three cases and one case had a single additional CD4+ lymphocyte. Neither
CD8 + nor CD4 + lymphocytes were present in the endometrium with inactive glands.

Stratum compactum and stratum spongiosum: The vast majority of immune cells were lymphocytes; only two tissue samples contained occasional macrophages, i.e. one and four CD172a+ macrophages within the stratum compactum and stratum spongiosum of one mare and five CD206+ macrophages within the stratum compactum of another mare.

Lymphocytes were exclusively composed of T cells. In addition, rare plasma cells were observed. T cell numbers within the stratum compactum were $2-4.5 \times$ higher than those detected within the stratum spongiosum. The ratio between CD4 + and CD8 + T cells varied considerably (stratum compactum: $26 \%, 103 \%$ and $148 \%$; stratum spongiosum: $17 \%$, $29 \%, 117 \%)$. In three endometria the sum of the CD4+ and CD8 + cell numbers was lower than the counted number of CD3 + cells. Notably, the inactive endometrium of one mare contained only T cells without detectable CD4 + and CD8+ cells, this suggests the presence of mainly CD4-/CD8- double negative T cells (CD4-/CD8- DN T cells).

Endometria with superficial non-suppurative endometritis Luminal and glandular epithelium: Occasional to small numbers of intraepithelial mononuclear cells were observed in all cases. These were composed exclusively of T lymphocytes. All examined endometria contained intraepithelial CD8+ lymphocytes and in eight cases 1 to 3 additional CD4+ lymphocytes were observed.

\begin{tabular}{|c|c|c|c|c|}
\hline Group A & $\begin{array}{c}\text { Str. comp. } \\
\text { Cells in } 5 \text { HPFs }\end{array}$ & $\begin{array}{l}\text { Str. spong. } \\
\text { Cells in } 5 \mathrm{HPFs}\end{array}$ & $\begin{array}{c}\text { LE } \\
\text { Cells in } 5 \text { HPFs }\end{array}$ & $\begin{array}{c}\text { GE } \\
\text { Cells in } 5 \text { HPFs }\end{array}$ \\
\hline CD172a & $(0-1)$ & $(0-4)$ & - & - \\
\hline CD14 & - & - & - & - \\
\hline CD206 & $(0-5)$ & - & - & - \\
\hline CD3 & $88(74-96)$ & $32(21-44)$ & $10(4-17)$ & $16(5-26)$ \\
\hline CD4 & $23(18-38)$ & $4(0-14)$ & $(0-1)$ & $(0-1)$ \\
\hline CD8 & $33(25-69)$ & $6(0-12)$ & $2(0-4)$ & $4(0-12)$ \\
\hline CD20 & - & - & - & - \\
\hline Plasma cells & $(0-2)$ & $(0-1)$ & - & - \\
\hline Group B & $\begin{array}{c}\text { Str. comp. } \\
\text { Cells in } 5 \text { HPFs }\end{array}$ & $\begin{array}{l}\text { Str. spong. } \\
\text { Cells in } 5 \text { HPFs }\end{array}$ & $\begin{array}{c}\text { LE } \\
\text { Cells in } 5 \text { HPFs }\end{array}$ & $\begin{array}{c}\text { GE } \\
\text { Cells in } 5 \text { HPFs } \\
\end{array}$ \\
\hline CD172a & $5(0-22)$ & $3(0-19)$ & $(0-1)$ & - \\
\hline CD14 & - & - & - & - \\
\hline CD206 & $(0-8)$ & $(0-16)$ & - & - \\
\hline CD3 & $244(129-478)$ & $86(26-193)$ & $17(3-51)$ & $25(9-59)$ \\
\hline CD4 & $56(0-172)$ & $8(0-38)$ & $(0-3)$ & $(0-1)$ \\
\hline CD8 & $88(10-197)$ & $27(0-69)$ & $5(0-13)$ & $8(0-24)$ \\
\hline CD20 & $2(0-10)$ & $1(0-6)$ & - & $(0-1)$ \\
\hline Plasma cells & $22(2-115)$ & $3(0-18)$ & $(0-1)$ & $(0-1)$ \\
\hline
\end{tabular}

$\mathrm{GE}=$ glandular epithelium; LE = luminal epithelium; Str. comp. = Stratum compactum; Str. spong. = Stratum spongiosum;

Cells in $5 \mathrm{HPFs}=$ cell counts were calculated in 5 high power fields ( $5 \mathrm{HPFs}$ ) by the use of serial sections;

- = absent; $n\left(n^{1}-n^{2}\right): n=$ average cell count, $n^{1}=$ minimal cell count, $n^{2}=$ maximal cell count 
Fig. 3 Semiquantitative evaluation of CD172a-, CD14- and CD206-immunopositive macrophages within the stratum compactum of the equine endometrium. Nos. 1-4: Mares without endometritis; Nos. 5-28: Mares with a mild superficial nonsuppurative endometritis. Mares without endometritis contain lower average numbers of CD172a-labelled macrophages than mares with an inflammatory reaction. All mares are negative for the detection of CD14-positive macrophages. Only in 3 mares (Nos. 3,16,17) CD206-immunopositive macrophages are detected.

Semiquantitative Evaluation von CDI72a-, CD14- und CD206-immunpositiver Makrophagen innerhalb des Stratum compactum des equinen Endometriums. Nr. 1-4: Stuten ohne Endometritis; Nr. 5-28: Stuten mit einer geringgradigen oberflächlichen nichteitrigen Endometritis. Endometrien von Stuten ohne Endometritis enthalten eine geringere

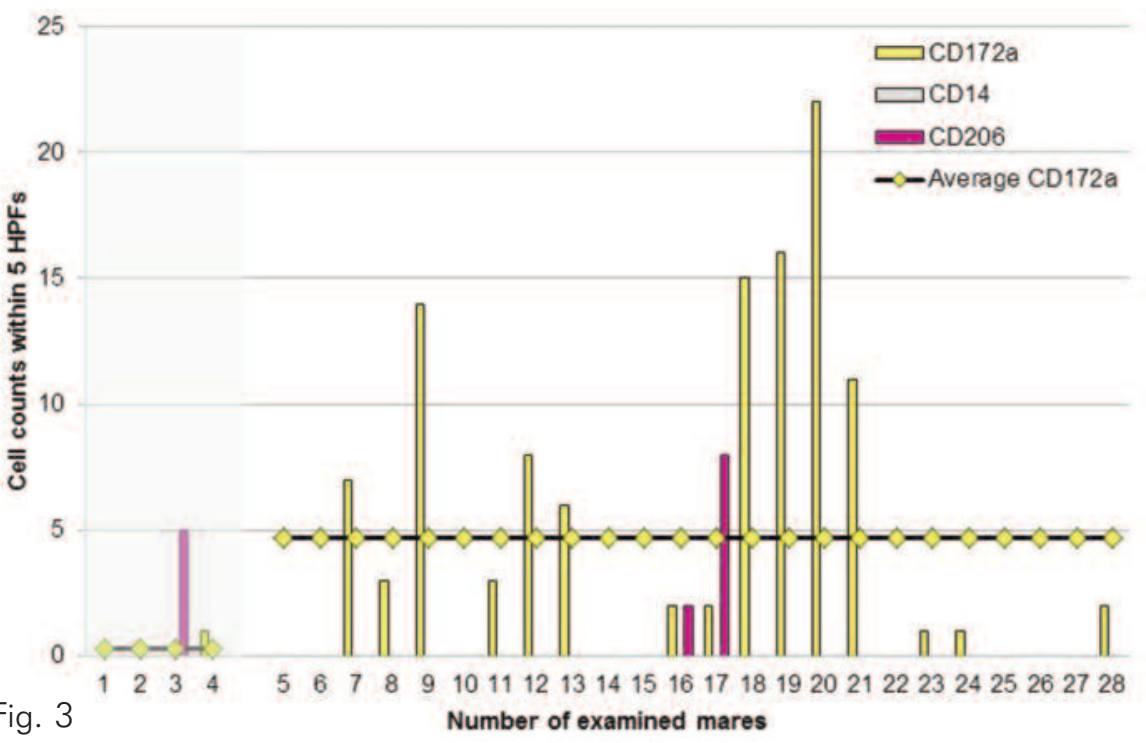
durchschnittliche Anzahl an CD172a-positiven Makrophagen als Endometrien von Stuten mit einer Entzündung. Alle untersuchten Endometrien sind negativ für den Nachweis von CD 14-positiven Makrophagen. In lediglich 3 Stuten (Nr. 3, 16,17) finden sich CD206-positive Makrophagen.

Fig. 4 Semiquantitative analysis of CD3-, CD4- and CD8- immunopositive lymphocytes within the stratum compactum of the equine endometrium. Nos. 1-4: Mares without endometritis; Nos. 5-28: Mares with a mild superficial non-suppurative endometritis. Increased average numbers of all examined lymphocytic cell populations are detected in mares with endometritis compared to mares without endometritis.

Semiquantitative Analyse CD3-, CD4- und CD8- immunpositiver Lymphozyten innerhalb des Stratum compactum des equinen Endometriums. Nr. 1-4: Stuten ohne Endometritis; Nr. 5-28: Stuten mit einer geringgradigen oberflächlichen nicht-eitrigen Endometritis. In Stuten mit einer Endometritis liegt eine höhere durchschnittliche Anzahl aller untersuchter lymphozytärer Zellpopulationen vor als in Stuten ohne Endometritis.

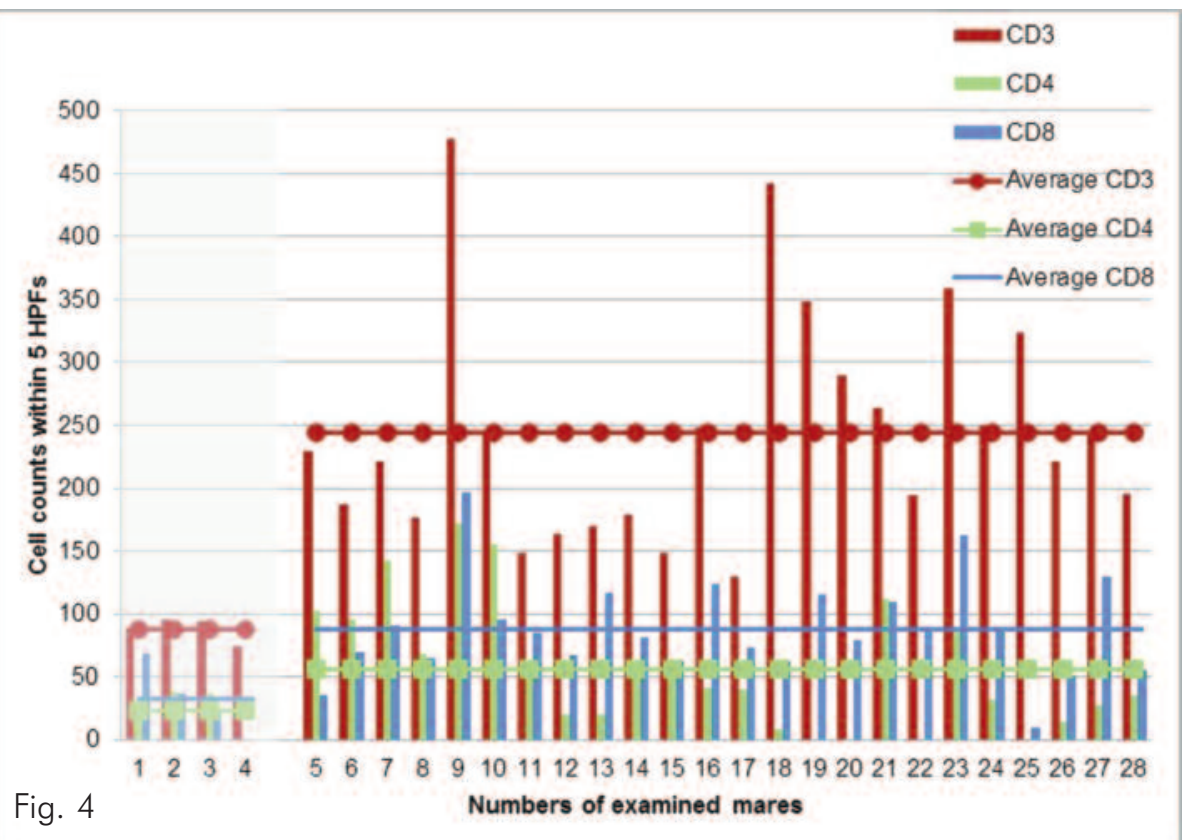

Stratum compactum: In 15 of 24 cases (63\%) occasional to small numbers of CD172a+ macrophages were observed within the stratum compactum (Figure 5A), two of these mares (8\%) contained additional CD206+ macrophages. Average macrophage counts were slightly higher than those of endometria without endometritis.

The majority of mononuclear cells were T lymphocytes. Their average cell count was approximately $3 \times$ higher than this value obtained from endometria without endometritis. The ratio between $\mathrm{CD} 4+$ and $\mathrm{CD} 8+\mathrm{T}$ cells varied considerably between individual mares ranging from $13 \%$ to $286 \%$. In four cases (17\%) only CD8+ lymphocytes were detected. In $92 \%$ of the cases the sum of CD4+ and CD8+ cells was lower than the CD3+ lymphocyte count indicating the presence of CD4-/CD8- DN T cells.

B lymphocytes were observed in 15 of 24 cases $(63 \%)$ in occasional to small numbers ( $1-10$ cells per 5 HPFs). Plasma

cells were present in the endometrium of all mares. The average number of plasma cells was $22 \times$ higher than in noninflamed endometria. The highest numbers of plasma cells were detected in a mare with an urovagina (1 15 plasma cells per 5 HPFs) and a mare with a positive bacterial culture (105 plasma cells per $5 \mathrm{HPFs})$. In all the other cases, plasma cell counts varied between 2 to 56 cells per 5 HPFs.

Stratum spongiosum: The vast majority of mononuclear cells were identified as T lymphocytes; macrophages, B lymphocytes and plasma cells were only occasionally detected. Overall, lower cell numbers of all examined mononuclear cell populations were present within the stratum spongiosum than within the stratum compactum; this is consistent with a superficial endometritis. Marked differences in the ratio between CD4 + and CD8+ lymphocytes were observed (5-131\%). In 21 of $24(88 \%)$ of the cases T cell numbers were higher than the sum of CD4 + and CD8 + lymphocytes indicating the participation of CD4-/CD8- DN T cells. In six cases (25\%) only 
CD8 + cells were observed and in one case no CD4 + or CD8 + cells were identified.

Tissue samples of a mare with marked non-suppurative and histiocytic endometritis

The histopathological examination revealed a marked superficial and deep non-suppurative and histiocytic endometritis together with a marked perivasculitis and vasculitis. The vast majority of histiocytic cells was arranged in variably sized aggregates and had an epithelioid morphology. Histiocytic cells were CD172a immunopositive and immunonegative for CD1 4 and CD206. Scattered individualized macrophages stained immunopositive for lysozyme- and/or myeloid/histiocyte-antigen (Figure 5B). Immunopositive lymphocytes were exclusively composed of T cells; CD20 + B cells and plasma cells were absent. The majority of T lymphocytes (approximately $45 \%$ ) were identified as CD8+ cells; no CD4+ cells were detected. This indicates that numerous CD3+ lymphocytes represent CD4-/CD8- DN T lymphocytes.

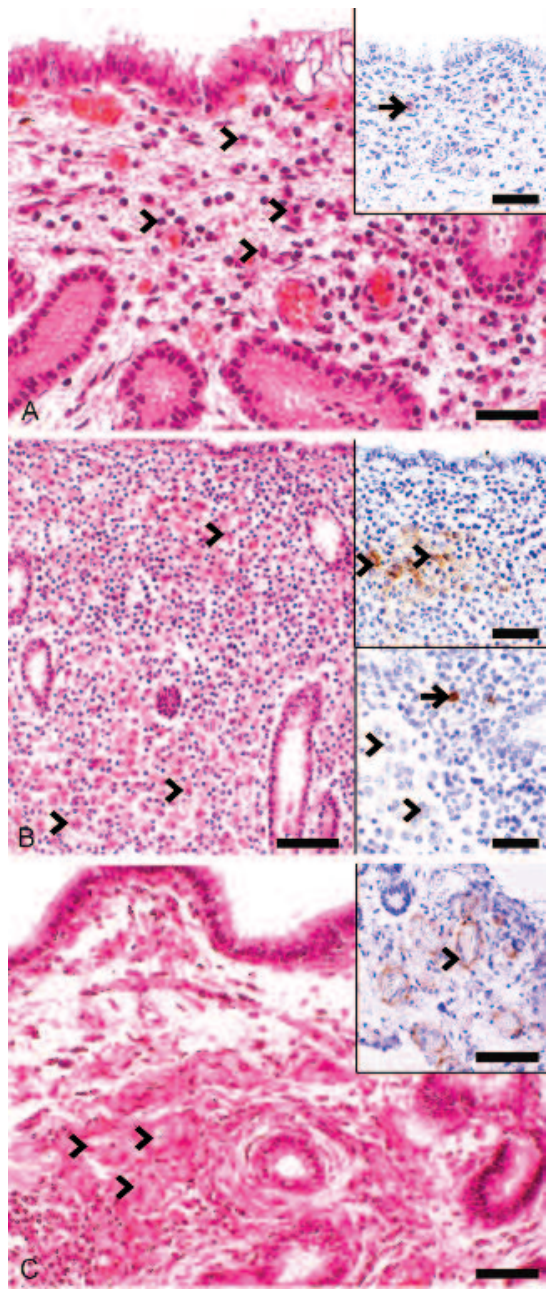

Fig. 5 (A) Endometrial biopsy of a mare with a mild superficial non-suppurative endometritis. Inflammatory mononuclear cells within the stratum compactum are labelled by arrowheads. HE. Bar $=20 \mu \mathrm{m}$. Inset: The inflamed stratum compactum contains a few CD172a immunopositive macrophages (arrow). Bar $=20 \mu \mathrm{m}$. (B) Endometrial tissue sample of a mare with a marked lymphohistiocytic endometritis. Clustered epithelioid macrophages (arrowheads) are surrounded by numerous lymphocytes. HE. Bar $=50 \mu \mathrm{m}$. Upper inset: Epithelioid macrophages are CD172a immunopositive (arrowheads). Bar $=20 \mu \mathrm{m}$. Lower inset: Myeloid/histiocyte (MAC387) immunostaining reveals a positive labelling of rare macrophages (arrow), whereas epithelioid cells are immunonegative (arrowheads). Bar $=20 \mu \mathrm{m}$. (C) Endometrial biopsy of a 20-year-old mare with multifocal moderate granulomatous endometritis. The stratum spongiosum has oligofocal granulomas with the presence of mono- and multinucleated histiocytic cells. A moderate number of these cells contain intracytoplasmic refractile foreign material (arrowheads). HE. Bar $=50 \mu \mathrm{m}$. Inset: Histiocytic cells including the multinucleated cell express CD172a antigen (arrowhead). Bar $=20 \mu \mathrm{m}$.

(A) Endometriumbioptat einer Stute mit einer geringgradigen oberflächlichen nicht-eitrigen Endometritis. Die mononukleären Entzündungszellen (Pfeilspitzen) sind auf das Stratum compactum beschränkt. HE. Messbalken $=20 \mu \mathrm{m}$. Inset: Wenige CD172aimmunpositive Zellen sind im entzündlich veränderten Stratum compactum vorhanden. Messbalken $=20 \mu \mathrm{m}$. (B) Endometriale Gewebeprobe einer Stute mit einer hochgradigen lymphohistiozytären Endometritis. Aggregierte epitheloide Makrophagen (Pfeilspitzen) sind von zahlreichen Lymphozyten umgeben. HE. Messbalken $=50 \mu \mathrm{m}$. Oberes Inset: Epitheloide Makrophagen sind CD172a-immunpositiv (Pfeilspitzen). Messbalken $=20 \mu \mathrm{m}$. Unteres Inset: Myeloid/histiocyteMarker wird von vereinzelt liegenden Makrophagen exprimiert (Pfeil). Epitheloide Makrophagen zeigten keine immunhistochemische Reaktion (Pfeilspitzen). Messbalken $=20 \mu \mathrm{m}$. (C) Endometriumbioptat einer 20 Jahre alten Stute mit einer mittelgradigen granulomatösen Endometritis. Im Stratum spongiosum finden sich oligofokal Granulome. Zahlreiche histiozytäre Zellen enthalten intrazyłoplasmatisches Fremdmaterial (Pfeilspitzen). HE. Messbalken $=50 \mu \mathrm{m}$. Inset: Histiozytäre Zellen einschließlich der multinukleären Zellen exprimieren CD172a-Antigen (Pfeilspitze). Messbalken $=20 \mu \mathrm{m}$.

A similar type of inflammation was observed within intestines, lymph nodes, uvea, the choroid plexus of the brain, myocard, skeletal muscles, adrenal glands and lungs. Special stains for the detection of intralesional mycobacteria (Ziehl-Neelsen stain, Fite-Faraco stain) and fungi or yeasts (PAS reaction) were negative.

Bacterial culture revealed a mild growth of Pseudomonas spp. and Staphylococcus epidermidis within the small intestine. The physiological microflora of the gut was absent. Within the other organs (lungs, liver, spleen, kidney) neither bacteria nor fungi could be cultured. Immunohistochemistry for Equine Herpesvirus-1, pseudorabies, rabies and Bornavirus as well as PCR for Borrelia spp. were negative.

Tissue samples of two mares with granulomatous endometritis

The granulomatous endometritis of the 21 -year-old mare was characterized by multifocal accumulation of mainly mononuclear histiocytic cells (slightly CD172a+ and CD206-) with lipid droplets (Sudan red stain positive) admixed with moderate numbers of lymphocytes and plasma cells. In the endometrium of the 20-year-old mare, the stratum spongiosum contained oligofocal granulomas with the presence of CD172a+ and CD206- mono- and multinucleated histiocytic cells (Figure 5C).

\section{Discussion}

Immunohistochemistry for the detection of macrophages in fixed equine tissues - establishment of this method

The present study established the methods for the immunohistochemical detection of CD172a, CD14 and CD206 in 
fixed and paraffin embedded tissue samples and showed their suitability for the analysis of macrophages in endometrial biopsy samples submitted for a routine diagnostic work-up.

The applied monoclonal antibodies were selected, since their cross-reactivity with equine tissue has been shown (CD172a, CD206: Dakin et al. 2012; CD14 1 ). To the best of the authors' knowledge, no published data on the application of these antibodies on fixed and paraffin embedded equine tissue samples have been published. Previously, these antibodies were used for immunostaining of cryostat sections of native tissue (Dakin et al. 2012, Flaminio et al. 2007, Kumar and Timoney 2005, Tumas et al. 1994).

The transmembrane protein CD172a, also known as signal regulatory protein alpha $(S I R P \alpha)$, is mainly expressed by myeloid cells (Barclay and van den Berg 2014, Taylor et al. 2005). It shows mostly a constitutive expression that is not influenced by inflammatory conditions (Barclay and van den Berg 2014). This receptor mediates homeostasis of haematopoietic cells and regulates phagocytosis, but is also involved in the pathogenesis of autoimmune diseases (Barclay and van den Berg 2014, Murata et al. 2014). The applied antiCD172a antibody has been proposed as pan-macrophage marker in equine tissue (Dakin et al. 2012, Tumas et al. 1994).

CD14 is also a receptor of myeloid cells (Taylor et al. 2005). It is activated by microbial ligands, in particular lipopolysaccharide (LPS), and associates with TLR4 or less commonly with TLR2 (Taylor et al. 2005, Arroyo-Espliguero et al. 2004). LPS can induce M1 polarization (Martinez and Gordon 2014, Taylor et al. 2005). Thus, CD1 4 has been suggested as marker for M1 macrophages in equine tissue (Dakin et al. 2012).

CD206, a mannose receptor, is expressed by macrophages and exerts a major role in physiological clearance, pathogen recognition and antigen presentation (Taylor et al. 2005). Its expression is upregulated by IL-4 and IL-10; these cytokines mediate M2 polarization (Martinez and Gordon 2014, Taylor et al. 2005). Therefore, the anti-mannose receptor antibody (CD206) has been proposed to identify M2 macrophages in horses (Dakin et al. 2012). The applied anti-CD172a and anti-CD1 4 antibodies also stain granulocytes (Tumas et al. 1994, Ziegler-Heitbrock and Ulevitch 1993). Both types of immunolabelled cells, however, can be distinguished by their typical characteristic histomorphological features. In human beings, CD172a is present on mast cells as well (Florian et al. 2005) and CD1 4 may be expressed by activated B cells (Ziegler-Heitbrock and Ulevitch 1993). Immunolabelling of these cell populations was ruled out by comparing CD172a or CD14 immunostained sections with serial sections treated with special stains for the detection of mast cells and plasma cells, respectively. Since hepatic sinusoidal endothelial cells and Kupffer cells are CD206 ${ }^{2}$ immunopositive as well, liver is recommended as positive control (Taylor 2005).

This study shows that immunostaining for CD172a and CD206 can be achieved in equine FFPE material, whereas the zinc-salt fixation allowed the detection of all examined macrophage markers in paraffin embedded tissue sections. This fixation method also permits the identification of CD4+ and CD8+ lymphocytes (Huth et al. 2014). It represents an excellent method for the routine diagnostic histological examination of an endometrial biopsy, since it is not cost expensive, available as a ready for use solution and ensures an excellent preservation of the tissue architecture (Huth et al. 2014). Further, the selected marker for M1 and $M 2$ macrophages (IgG2a anti-CD14- and lgG1 anti-CD206-antibodies) are suitable for double-immunostaining studies to identify both macrophage types within the same tissue section.

This study indicates that CD172a can be used as pan-macrophage marker in the equine endometrium as well; it labelled macrophages including their morphological derivates, i.e. epithelioid cells and multinucleated giant cells. This finding was confirmed within the endometrium of the mare with the non-suppurative and histiocytic endometritis, i.e. CD172a identified all histiocytic cells, whereas only scattered macrophages excluding the epithelioid cells were lysozyme and myeloid/histiocyte immunopositive. Anti-human myeloid/histiocyte antigen (clone MAC387) reacts with L1/calprotectin ${ }^{3}$, an antigen expressed by a subset of reactive macrophages as well as granulocytes (Brandtzaeg et al. 1992). Lysozyme production in macrophages appears to be associated with their phagocytic activity (Keshav et al. 1991). False positive cellular staining, however, can be evoked due to a passive uptake of extracellular calprotectin (Brandtzaeg et al. 1992) or lysozyme (Keshav et al. 1991).

MHC Class II molecules were used as marker for macrophages within the equine endometrium as well (Watson and Thomson 1996, Watson and Dixon 1993). These are present, however, on all antigen presenting cells, i.e. macrophages, dendritic cells and B cells as well as epithelial cells of the thymus and in humans on activated $T$ cells (Murphy et al. 2012). In the equine endometrium, lymphocytes and epithelial cells were also immunopositive (Watson and Dixon 1993).

Macrophage subsets of horses are only poorly characterized, whereas already detailed information on macrophage polarization markers in human beings (Thiruchelvam et al. 2013), mice (Gordon et al. 2014, Tan et al. 2014), bovine (Fernandez et al. 2017, Oliveira et al. 2010) and porcine (Ezquerra et al. 2009) exist. To the best of the authors' knowledge, there is only one previous study that aimed to identify M1 and $M 2$ macrophages in equine tissue by immunohistohemistry (Dakin et al. 2012). Dakin and colleagues proposed CD14 and CD206 as markers indicative of $M 1$ and $M 2$ polarization also in horses by extrapolating data obtained from mice and human beings (Dakin et al. 2012).

Immunohistochemical phenotyping of immune cell populations

Endometrial tissue samples of mares without endometritis and with superficial non-suppurative endometritis

The CD3 +, CD4+, CD8+ lymphocytes and plasma cells as well as CD172a+ and CD206+ macrophages detected within the healthy equine endometrium likely represent components of the normal uterine immune defence. The slightly higher numbers of immune cells within the stratum compactum than the stratum spongiosum indicate an increased cellular defence of 
the luminal surface. Indeed, exposure of the equine endometrium to infectious agents as well as other antigenic stimuli (lavage, insemination) mostly occurs via the uterine lumen.

Endometria without inflammation showed marked differences in the numbers of CD3+, CD4+ and CD8 + cells. Those individual differences are probable influenced by previous genital infections and their treatment, breeding, the number of pregnancies, the tissue environment (oxidative status, other diseases) and the general immune status of a mare. A contribution of genetic factors has to be considered as well.

The examined cases of non-suppurative endometritis are representative for those usually encountered during the routine examination of equine endometrial biopsies (Schoon et al. 1997). This study showed non-suppurative endometritis is mainly a $T$ cell mediated disease with involvement of mild to moderate numbers of plasma cells. Small numbers of macrophages and/or B cells were detected in 63\% (15 of 24) of the cases. The present results confirm the findings of a previous preliminary investigation (Huth et al. 2014) that endometria with non-suppurative endometritis are characterized by a high variability in the numbers of CD3 +, CD4 + and CD8+ cells. Thus, despite the uniform light microscopic finding of nonsuppurative endometritis, phenotyping of involved immune cells suggests the existence of different disease subtypes that may even differ in their pathogenesis and etiology. The clonal expansion of resident immune cells, however, may also contribute to the variability in the relative numbers of particular immune cell populations within the inflamed endometrium.

This investigation suggests the presence of variable numbers of CD4-/CD8- DN T lymphocytes within the healthy and diseased equine endometrium. DN T cells may fulfill an immunoregulatory function by suppressing antigen specific immune reactions (regulatory DN T cells), but can also mediate autoimmune diseases (inflammatory DN T cells; D'Acquisito et al. 2011 ). The factors that determine the biological behavior of DN T cells, i.e. immunosuppressive or -aggressive, are not full known. It has been shown, however, that in the healthy female genital tract of mice regulatory DN T cells encompass $70-90 \%$ of the total lymphocytes (Johansson and Lycke 2003).

The detected CD4 + and CD8 + cells likely represent predominately Th1/Th2 cells and Tcl/Tc2 lymphocytes, respectively. A contribution of IL-17 producing lymphocytes (Th17, Tc 17) as well as CD4 + or CD8 + regulatory T cells has to be considered as well (Vuddamalay and Meerwijk 2017, Srenathan et al. 2016, Murphy et al. 2012).

In horses, macrophages may also bear CD4 and CD8 receptors (Grünig et al. 1995). Since different immune cell populations may express identical cellular markers, results of the immunostaining have to be interpreted under consideration of the cellular morphology. In the pesent case, no CD4+ and/or CD8 + macrophages were detected.

The higher average numbers of macrophages within endometria with non-suppurative endometritis than in those without inflammation suggests their involvement in the pathogenesis of this disease. Similarly, slightly elevated numbers of macrophages were detected in the endometrium of cows with subclinical endometritis and repeated breeding (Barański et al. 2012).

Whereas in $57 \%$ (16 of 28 ) of the examined biopsies of healthy and diseased endometria CD172a+ macrophages were observed, only 11\% (3 of 28) contained CD206+ macrophages and none CD14+ macrophages. This indicates a very limited expression of CD206 and CD1 4 on macrophages of the equine endometrium. The absence of CD14 on endometrial macrophages is further supported by the finding that histiocytic cells of the mare with the non-suppurative and histiocytic endometritis were immunonegative for TLR4, the main co-receptor of CD14 (data not shown).

The low (CD206) or absent (CD14) detection of these markers may be explained by tissue and species specific differences in the expression of monocyte and macrophage markers (i.e. mice and human: Gordon et al. 2014, Gordon and Taylor 2005), in particular since the endometrium of the mare is equipped with unique immunological regulatory mechanisms ("split immunological tolerance", de Mestre et al. 2010). The few observed CD206+ macrophages, however, suggest that in horses at least some endometrial macrophages differentiate along an M2 pathway. The activating factors have still to be identified; a progesterone influence has to be considered, since all mares with CD206 + endometrial macrophages had a secretory glandular differentiation. The activation of the M2 pathway occurs in the healthy pregnant endometrium of women (Nagamatsu and Schust 2010) and cows (Oliveira et al. 2010). In comparison, women with recurrent miscarriages contained elevated numbers of M1 macrophages within the endometrium (Wang et al. 2011).

The polarization of macrophages can also be markedly influenced by the tissue environment (Gordon et al. 2014). In this study, $82 \%$ of examined biopsies (23 of 28) had angiosclerosis. This is a frequent alteration in adult mares show varying degrees of endometrial angiosclerosis; its frequency and severity are influenced by the mare's age and pregnancy rates (Schoon et al. 1997). It is known that the oxidative status influences the level as well as the type of immune responses including the polarization of macrophages (Crowther et al. 2004, Kidd 2003).

In the mare with the non-suppurative and histiocytic endometritis and similar inflammatory changes in several other organs, the absence of a detectable infectious etiology is suggestive of an immune-mediated pathogenesis. This case shows that in rare cases inflammation of the equine endometrium is not a localized primary disease, but occurs as part of a multisystemic disease.

\section{Conclusion and future perspectives}

This study shows that immunohistochemistry on zinc fixed paraffin embedded equine endometrial biopsies allows phenotyping of immune cells. The established method can be included in the routine diagnostic work-up of equine endometrial biopsies and obtained data can be directly correlated with the light microscopic findings. Immunophenotyping can provide important disease related information, for example, results of this study indicate that non-suppurative endometritis inclu- 
des several subtypes. The characterization of disease associated immune cells can have therapeutic and prognostic relevance. It will likely assist to identify therapeutic targets and the polarization of immune cells may influence the disease outcome, i.e. resolution, persistence or progression. The standardized application of this method will also help to identify the immunological mechanisms that determine if a mare is predisposed to develop persistent endometritis. The successful future application of this method will likely be beneficial for the genital health of individual mares as well as may help to prevent financial losses of the horse breeding industry.

\section{Footnotes}

1 Manufacturers instruction:biometec $\mathrm{GmbH}$, BioTechnikum, Greifswald, Germany

2 Manufacturers instruction: abcam, England, UK

3 Manufacturers instruction: DAKO North America Inc., California, USA

\section{Acknowledgements}

The authors thank Mrs Wipplinger and the histology laboratory (Leipzig University) for excellent technical support. We are grateful to Prof. Dr. Sieme, PD Dr. Bartmann, Dr. Edzards and the colleagues of the Clinic for horses (Leipzig University) for submission of endometrial tissue samples.

\section{References}

Arroyo-Espliguero R., Avanzas P., Jeffery S., Kaski J. C. (2004) CD14 and toll-like receptor 4: a link between infection and acute coronary events? Heart 90, 983-988

Bain C. C., Mowat A. M. (2014) Macrophages in intestinal homeostasis and inflammation. Immunol. Rev. 260, 102-117

Barański W., Kaleczyc J., Zduńczyk S., Podlasz W., Długołecka-Malinowska E., Janowski T. (2013) Distribution of CD14+ macrophages, CD4+, CD8+ lymphocytes and mRNA expression of inducible nitric oxide synthase in the endometrium of repeat breeding cows. Pol. J. Vet. Sci. 16, 443-451

Barclay A. N., van den Berg T. K. (2014) The interaction between signal regulatory protein alpha (SIRP) and CD47: structure, function, and therapeutic target. Annu. Rev. Immunol. 32, 25-50

Brandtzaeg P., Dale I., Gabrielsen T.-O. (1992) The leucocyte protein L1 (calprotectin): usefulness as an immunohistochemical marker antigen and putative biological function. Histopathology 21 , $191-196$

Brunckhorst D., Schoon H. -A., Bader H., Sieme H. (1991) [Morphological, enzymatic and immunohistochemical characteristics of the endometrial cycle in the mare.] [in German]. Fertilität 7, 44-51

Crowther M., Brown N. J., Bishop E. T., Lweis C. E. (2001) Microenvironmental influence on macrophage regulation of angiogenesis in wounds and malignant tumors. J. Leukoc. Biol. 70, 478-490

D'Acquisto F., Crompton T. (2011) CD3 + CD4-CD8- (double negative) T cells: Saviours or villains of the immune response? Biochem. Pharmacol. 82, 333-340

Dakin S. G., Werling D., Hibbert A., Abayasekara D. R., Young N. J., Smith R. K., Dudhia J. (2012) Macrophage sub-populations and the lipoxin A4 receptor implicate active inflammation during equine tendon repair. PloS One 7, e32333

De Mestre A. (2013) Reproductive failure in horses: identifying the problem. Vet. Rec. 172, 42-43

De Mestre A., Noronha L., Wagner B., Antczak D. F. (2010) Split immunological tolerance to trophoblast. Int. J. Dev. Biol. 54, 445-455
Ebert A., Schoon D., Schoon H.-A. (2014) Age related endometrial alterations in mares - biopsy findings of the last 20 years. Leipziger Blave Hefte: Proc. 8th International Conference on Equine Reprod. Med. 2, 230-232

Ellenberger C., Schoon D., Schoon H.-A. (2006) [Exceptional diagnostic findings in uterine biopsies of the mare.] [in German]. Pferdeheilkunde 22, 171-176

Ezquerra A., Revilla C., Alvarez B., Pérez C., Alonso F., Domínguez J. (2009) Porcine myelomonocytic markers and cell populations. Dev. Comp. Immunol. 33, 284-298

Fernández M., Benavides J., Castaño P., Elguezabal N., Fuertes M., Muñoz M., Royo M., Ferreras M. C., Pérez V. (2017) Macrophage subsets within granulomatous intestinal lesions in bovine paratuberculosis. Vet. Pathol. 54, 82-93

Flaminio M. J., Ibrahim S., Lunn D. P., Stark R., Steinbach F. (2007) Further analysis of anti-human leukocyte mAbs with reactivity to equine leukocytes by two-colour flow cytometry and immunohistochemistry. Vet. Immunol. Immunopathol. 119, 92-99

Florian S., Ghannadan M., Mayerhofer M., Aichberger K. J., Hauswirth A. W., Schernthaner G.-H., Printz D., Fritsch G., Böhm A., Sonneck K., Krauth M.-T., Müller M. R., Sillaber C., Sperr W. R., Bühring H.-J., Valent P. (2005) Evaluation of normal and neoplastic human mast cells for expression of CD172a (SIRP), CD47, and SHP-1. J. Leukoc. Biol. 77, 984-992

Gordon S., Plüddemann A., Martinez Estrada F. (2014) Macrophage heterogeneity in tissues: phenotypic diversity and functions. Immunol. Rev. 262, 36-55

Gordon S., Taylor P. R. (2005) Monocyte and macrophage heterogeneity. Nat. Rev. Immunol. 5, 953-964

Grünig G., Triplett L., Canady L. K., Allen W. R., Antczak D. F. (1995) The maternal leucocyte response to the endometrial cups in horses is correlated with the developmental stages of the invasive trophoblast cells. Placenta 16, 539-559

Huth N., Schöniger S., Sieme H., Bartmann C.-P., Schoon H.-A. (2014) Lymphocyte subpopulations in the equine endometrium: a methodical approach with diagnostic implications. Pferdeheilkunde 30, 4-14

Johansson M., Lycke N. (2003) A unique population of extrathymically derived TCR +CD4-CD8- T cells with regulatory functions dominates the mouse female genital tract. J. Immunol. 170, 1659-1666

Kenney R. M., Doig P. A. (1986) Equine endometrial biopsy. In: Morrow D. A., editor: Current therapy in Theriogenology. 2nd ed. Philadelphia: WB Saunders, 723-729

Keshav S., Chung P., Milon G., Gordon S. (1991) Lysozyme is an inducible marker of macrophage activation in murine tissues as demonstrated by in situ hybridization. J. Exp. Med. 174, 1049-1058

Kidd P. (2003) Th1/Th2 balance: the hypothesis, its limitations, and implications for health and disease. Altern. Med. Rev. 8, 223-246

Kumar P., Timoney J. F. (2005) Histology, immunohistochemistry and ultrastructure of the equine lingual tonsil. II. Lymphoid tissue associated high endothelial venules. Anat. Histol. Embryol. 34, 98 104

Kydd J., Antczak D. F., Allen W. R., Barbis D., Butcher G., Davis W., Duffus W. P., Edington N., Grünig G., Holmes M. A., Lunn D.P., McCulloch J., O'Brien A., Perryman L. E., Tavernor A., Williamson S., Zhang C. (1994) Report of the first international workshop on equine leucocyte antigens, Cambridge,UK, July 1991. Vet. Immunol. Immunopathol. 42, 3-60

LeBlanc M. M., Causey R. C. (2009) Clinical and subclinical endometritis in the mare: both threats to fertility. Reprod. Dom. Anim. 44 (Suppl. 3), 10-22

Martinez F. O., Gordon S. (2014) The M1 and M2 paradigm of macrophage activation: time for reassessment. F1000Prime Rep. 6,13

Mills C. D., Kincaid K., Alt J. M., Heilman M. J., Hill A. M. (2000) M-1/M-2 macrophages and the Th1/Th2 paradigm. J. Immunol. 164, 6166-6173

Murata Y., Kotani K., Ohnishi H., Matozaki T. (2014) The CD47 SIRP signalling system: its physiological roles and therapeutic application. J. Biochem. 155, 335-344 
Murphy K., Janeway Jr. C. A., Travers P., Walport M., Mowat A., Weaver C. T. (2012) Janeway's Immunobiology, 8th edition. Garland Science, Taylor and Francis Group, New York, USA. 8th ed.

Nagamatsu T., Schust D. J. (2010) The contribution of macrophages to normal and pathological pregnancies. Am. J. Reprod. Immunol. 63, 460-471

Oliveira L. J., McClellan S., Hansen P. J. (2010) Differentiation of the endometrial macrophage during pregnancy in the cow. PloS One. 5, e 13213

Schoon H.-A., Wiegandt I., Schoon D., Aupperle H., Bartmann C.-P. (2000) Functional disturbances in the endometrium of barren mares: a histological and immunohistological study. J. Reprod. Fertil. Suppl. 56, 381-391

Schoon H.-A., Schoon D., Klug E. (1997) [The endometrial biopsy in the mare with regard to clinical correlations.] [in German]. Pferdeheilkunde 13, 453-464

Schoon H.-A., Schoon D., Klug E. (1992) [Endometrial biopsies as an ancillary aid in diagnosis and prognosis of subfertility in the mare.] [in German]. Pferdeheilkunde 8, 355-362

Srenathan U., Steel K., Taams L. S. (2016) IL-17+ CD8+ T cells: Differentiation, phenotype and role in inflammatory disease. Immunol. Lett. 178, 20-26

Tan W., Chen L., Guo L., Ou X., Xie D., Quan S. (2014) Relationship between macrophages in mouse uteri and angiogenesis in endometrium during the peri-implantation period. Theriogenology. $82,1021-1027$
Taylor P. R., Martinez-Pomares L., Stacey M., Lin H.-H., Brown G. D., Gordon S. (2005) Macrophage receptors and immune recognition. Annu. Rev. Immunol. 23, 901-944

Thiruchelvam U., Dransfield I., Saunders P. T., Critchley H. O. (2013) The importance of the macrophage within the human endometrium. J. Leukoc. Biol. 93, 217-225

Tumas D. B., Brassfield A. L., Travenor A. S., Hines M. T., Davis W. C., McGuire T. C. (1994) Monoclonal antibodies to the equine CD2 T lymphocyte marker, to a pan-granulocyte/monocyte marker and to a unique pan-B lymphocyte marker. Immunobiol. 192, 48-64

Vuddamalay Y, van Meerwijk J. P. M. (2017) CD28- and CD28lowCD8 + regulatory T cells: of mice and men. Front Immunol. 8,31

Wang W.-J., Hao C.-F., Lin Q.-D. (2011) Dysregulation of macrophage activation by decidual regulatory $\mathrm{T}$ cells in unexplained recurrent miscarriage patients. J. Reprod. Immunol. 92, 97-102

Watson E. D., Thomson S. R. (1996) Lymphocyte subsets in the endometrium of genitally normal mares and mares susceptible to endometritis. Equine Vet. J. 28, 106-1 10

Watson E. D., Dixon C. E. (1993) An immunohistological study of MHC Class II expression and T lymphocytes in the endometrium of the mare. Equine Vet. J. 25, 120-124

Woodland D. L., Dutton R. W. (2003) Heterogeneity of CD4+ and CD8+ T cells. Cur. Opin. Immunol. 15, 336-342

Ziegler-Heitbrock H. W., Ulevitch R. J. (1993) CD14: Cell surface receptor and differentiation marker. Immunol. Today 14, 121-125 